\title{
Astma i POChP - wyzwania terapeutyczne w dobie COVID-19
}

\section{Asthma and COPD - therapeutic challenges in the COVID-19}

\author{
dr hab. n. med. Adam J. Sybilski, prof. CMKP \\ II Klinika Pediatrii, Centrum Medyczne Kształcenia Podyplomowego w Warszawie \\ Klinika Chorób Dziecięcych i Noworodkowych z Centrum Alergologii i Dermatologii, \\ Centralny Szpital Kliniczny Ministerstwa Spraw Wewnętrznych i Administracji w Warszawie
}

\begin{abstract}
Streszczenie:
Infekcje wirusowe, w tym koronawirusowe, powodują zaostrzenia astmy i POChP. Ostatnie badania dowodzą jednak, że astma nie jest czynnikiem ryzyka ciężkiego przebiegu COVID-19, a SARS-CoV-2 jej nie zaostrza. Nie stwierdzono zwiększonego nasilenia objawów, zwiększonego ryzyka zgonu, częstości wentylacji mechanicznej i intubacji, długość pobytu, ponownego przyjęcia lub śmiertelności z powodu COVID-19 u chorych na astmę. Pacjenci z POChP są bardziej podatni na zakażenie koronawirusem i cięższy przebieg infekcji, co może być spowodowane zwiększoną ekspresją ACE2 (receptor dla SARS-CoV-2) w nabłonku oskrzeli i tkance płuc w tej grupie chorych oraz powiązaniem wyższego poziomu ekspresji ACE2 z niższz̨ czynnością płuc. Wśród pacjentów hospitalizowanych występowanie POChP jest istotnie skorelowane z większym nasileniem objawów COVID-19, co prowadzi do gorszego rokowania. Wspótwystępowanie COVID-19 z innymi przewlekłymi chorobami dróg oddechowych, takimi jak astma i POChP, stanowi nie lada wyzwanie terapeutyczne. Jednak, pomimo początkowych obaw, schematy oraz metody terapii astmy i POChP w dobie pandemii nie uległy zmianie. W astmie postępujemy zgodnie z wytycznymi GINA, a w POChP - rekomendacjami GOLD. Zaleca się, aby nie zmieniać planów leczenia ustalonych przez lekarzy i aby pacjenci kontynuowali terapię wziewną. Podstawą leczenia pozostają glikokortykosteroidy w postaci inhalacji. Obecnie w codziennej prakłyce telewizyty są dobrym rozwiązaniem w kontrolowaniu przebiegu astmy i POChP, podtrzymywaniu terapii i modyfikacji postępowania. Niestety w trakcie telewizyty nie jesteśmy w stanie skontrolować techniki przyjmowania leków wziewnych. Odpowiedzią na ten problem może być inhalator Forspiro ${ }^{\circledR}$, który ma unikalny mechanizm poprawnej techniki inhalacji. Jego cechy, takie jak: prosta, kompaktowa budowa umożliwiająca intuicyjne używanie, minimalna liczba wymaganych czynności przy stosowaniu, informacja zwrotna dla chorego o prawidłowym procesie inhalacji, mogą w znacznym stopniu ułatwić terapię stosowaną samodzielnie, w domu przez pacjenta.
\end{abstract}

\begin{abstract}
:
Viral infections, including coronaviruses, exacerbate asthma and COPD. Recent studies, however, show that asthma is not a risk factor for severe COVID-19, and SARS-CoV-2 does not exacerbate asthma. There was no evidence of increased symptom severity, risk of death, frequency of mechanical ventilation and intubation, length of stay, readmission, or mortality from COVID-19 in patients with asthma. Patients with COPD are more susceptible to coronavirus infection and a more severe course of infection, which may be due to increased expression of ACE2 (SARS-CoV-2 receptor) in bronchial epithelium and lung tissue in COPD patients and the association of higher levels of ACE2 expression with lower lung function. Among hospitalized patients, the occurrence of COPD is significantly correlated with a greater severity of COVID-19 symptoms, which leads to a worse prognosis. The coexistence of COVID-19 with other chronic respiratory diseases, such as asthma and COPD, is a real therapeutic challenge. However, despite initial concerns, routines and treatments for asthma and COPD did not change during the pandemic. In asthma, we follow the GINA guidelines, and in COPD, the GOLD recommendations. It is recommended not to modify treatment plans prescribed by physicians and that patients continue on inhalation therapy. The mainstay of treatment is inhaled glucocorticosteroids. Currently, in everyday practice, telemedical visit is a good solution for controlling the course of asthma and COPD, maintaining treatment, and modifying the procedure. Unfortunately, we are not able to control the technique of inhaling medication during the telemedical visit. The solution to this problem may be the Forspiro ${ }^{\circledR}$ inhaler, which has a unique mechanism of correct inhalation technique. Its features, such as: simple, compact design enabling intuitive use, minimal number of steps when used, feedback for the patient about the correct inhalation process, can greatly facilitate the therapy used alone, at home by the patient.
\end{abstract}

Słowa kluczowe: COVID-19, SARS-CoV-2, astma, POChP, leczenie

Key words: COVID-19, SARS-CoV-2, asthma, COPD, treatment 
W grudniu 2019 r. po raz pierwszy opisano nową chorobę układu oddechowego wywołaną przez koronawirusa ciężkiego ostrego zespołu oddechowego 2 (SARS-CoV-2, severe acute respiratory syndrome coronavirus 2) i nazwano ją ostrą chorobą koronawirusową układu oddechowego 2019 (COVID-19). Wstępne doniesienia pochodziły od grupy pacjentów z Wuhanu w Chinach, u których wystąpiło zapalenie płuc podobne do ciężkiego ostrego zespołu oddechowego (SARS). Zakażenie rozprzestrzeniało się dynamicznie na całym świecie, co spowodowało ogłoszenie 11 marca 2020 r. przez Światową Organizację Zdrowia (WHO, World Health Organization) pandemii COVID-19 i określenie tej choroby jako poważne zagrożenie dla zdrowia publicznego o zasięgu międzynarodowym $[1,2]$.

\section{Koronawirus SARS-CoV-2}

Koronawirusy są otoczkowymi wirusami z jednoniciowym genomem RNA, o średnicy od $60 \mathrm{~nm}$ do $140 \mathrm{~nm}$ z kolczastymi występami na powierzchni, nadającymi im wygląd przypominający koronę pod mikroskopem elektronowym. Należą do tzw. dużych wirusów RNA, ponieważ mają genom w zakresie od 26,4 do 31,7 knt. Cztery szczepy koronawirusa (HKU1, NL63, 229E i OC43) występowały w populacji ludzi i powodowały zazwyczaj łagodną chorobę układu oddechowego. W latach 2002-2003 (wirus SARS-CoV) i w 2012 r. (wirus MERS-CoV) miało miejsce przejście wirusów $\beta$-corona od zwierząt na ludzi, co zainicjowało ciężki przebieg zakażenia, czyli zespół ciężkiej ostrej niewydolności oddechowej (SARS, severe acute respiratory). Wirus SARS-CoV-2 (zwany także $\mathrm{HCoV}-19$, human coronavirus) w porównaniu z wirusami SARS i MERS jest mniej wirulentny ze znacznie niższymi wskaźnikami śmiertelności, za to dużo bardziej zakaźny, również w okresie bezobjawowym. Eliminacja nowego wirusa następuje najprawdopodobniej szybciej niż SARS i MERS, chociaż dane dotyczące przypadków krytycznych są w tym kontekście niejednoznaczne $[3,4]$.

\section{Obraz kliniczny COVID-19}

COVID-19 przebiega w trzech fazach klinicznych, przy czym progresja nie występuje u wszystkich pacjentów. Pierwszym etapem jest bezobjawowa faza inkubacji, która może przejść w fazę drugą - lekkoobjawową. Trzecia faza to ciężka choroba układu oddechowego [5]. Ta trzeciorzędowa faza ciężkiej choroby układu oddechowego jest spowodowana nasilonym zapaleniem płuc z zespołem ostrej niewydolności oddechowej (ARDS, acute respiratory distress syndrome) [6]. Uważa się, że etiologia ARDS w COVID-19 jest spowodowana nadmierną reakcją zapalną wywołaną uwolnieniem interferonu $\alpha$ i $\gamma$ (IFN- $\alpha$, IFN- $\gamma$ ), czynnika martwicy nowotworów (TNF- $\alpha$ ), interleukin $1 b$, $6,8,12$ oraz 18. Zjawisko to określa się nazwą burza cytokinowa [7]. Nasilenie tej trzeciorzędowej fazy koreluje ze stopniem zapalenia, na co wskazuje dodatnia zależność między ciężkim przebiegiem COVID-19 a stężeniem Il-6 i CRP we krwi [8].

\section{Patomechanizm zakażenia SARS-CoV-2}

Czynniki ryzyka cięższego przebiegu klinicznego COVID-19 można lepiej zrozumieć, biorąc pod uwagę mechanizm działania wirusa na poziomie komórkowym. Wirus SARS-CoV-2 zawiera białko S (spike) - białko wiążące receptor (RBD, receptorbinding domain), które łączy się z receptorami komórkowymi, umożliwiając wirusowi przedostanie się do komórek docelowych. Wykazano, że SARS-CoV wykorzystuje receptor enzymu konwertującego angiotensynę 2 (ACE2) do wejścia do komórki. Ostatnie badania pokazują, że RBD wirusa SARS-CoV-2 ma większe powinowactwo do białka receptorowego ACE2 (angiotensin-converting enzyme 2) niż innych koronawirusów. Im wyższe jest to powinowactwo, tym większa zdolność wirusa do infekowania komórek. Następnie wykazano, że z receptorem tym wiąże się białko S SARS-CoV-2. Jednak przed związaniem się z ACE2 białko S SARS-CoV-2 wymaga rozszczepienia przez komórkową proteazę serynową TMPRSS2 (transmembrane serine protease 2). ACE2 i TMPRSS2 ulegają koekspresji na komórkach kubkowych nabłonka nosa, pneumocytach typu 2 i enterocytach jelita krętego, co czyni je kluczowymi punktami dla zakażenia SARS-CoV-2 [2, 9].

Wykazano, że ekspresja genu $A C E 2$ w nabłon$\mathrm{ku}$ nosa wzrasta wraz $\mathrm{z}$ wiekiem, a ponadto wzrasta w komórkach nabłonka dróg oddechowych palaczy i pacjentów z przewlekłą obturacyjną chorobą płuc (POChP). Wiek, POChP i palenie tytoniu są związane ze zwiększonym ryzykiem wystąpienia ciężkiego COVID-19, dlatego też wysunięto teorię, że zwiększona ekspresja ACE2 może służyć jako mechanizm powodujący ciężki przebieg choroby [10-13]. U pacjentów $\mathrm{z}$ astmą atopową zmniejsza się ekspresja genu $A C E 2$ w komórkach nabłonkowych, czego nie zaobserwowano $\mathrm{u}$ chorych $\mathrm{z}$ astmą nieatopową. Trzeba również zaznaczyć, że gen $A C E 2$ jest stymulowany przez interferon, a zatem jego ekspresja wzrasta podczas infekcji 
wirusowych. Biorąc pod uwagę to, że komórki nabłonka oskrzeli u astmatyków mają wadliwą odpowiedź IFN- $\beta$ na infekcję wirusową, może to osłabić naturalny wzrost ekspresji ACE2 podczas infekcji SARS-CoV-2, ostatecznie zmniejszając nasilenie choroby [2].

\section{Znaczenie astmy w przebiegu COVID-19}

Wiadomo, że infekcje wirusowe powodują zaostrzenia astmy, a koronawirus jest jednym z najczęściej spotykanych w epizodach zaostrzeń astmy u dorosłych (w jednym $\mathrm{z}$ badań $\mathrm{HCoV}$ izolowano w 8,4\% wszystkich zaostrzeń) [14]. Przypuszczalnie na podstawie tych danych zarówno CDC (Centers for Diseases Control and Prevention), jak i WHO na początku pandemii COVID-19 wymieniły astmę jako czynnik ryzyka ciężkiej choroby [2].

Najnowsze doniesienia nie potwierdziły jednak tych obaw $[15,16]$. W tabeli 1 przedstawiono kilka badań potwierdzających hipotezę, że astma nie występuje częściej u pacjentów z COVID-19. Chociaż obecne dane dotyczące astmy i COVID-19 są prawie wyłącznie retrospektywne i mają oczywiste ograniczenia, zdecydowanie sugerują, że astma nie jest czynnikiem ryzyka ciężkiego przebiegu COVID-19, a SARS-CoV-2 nie zaostrza astmy. Liczne badania nie wykazały zwiększonego nasilenia choroby COVID-19 wśród przyjętych pacjentów z astmą. Nie stwierdzono zwiększonego ryzyka zgonu, częstości wentylacji mechanicznej i intubacji, długość pobytu, ponownego przyjęcia lub śmiertelności z powodu COVID-19 u pacjentów z astmą [16, 18, 20-24]. Tylko w jednym badaniu w Korei Południowej stwierdzono, że astma wiąże się z niewielkim zwiększeniem ryzyka ciężkiej choroby $(\mathrm{OR}=1,08$; CI 1,01-1,17), które definiowano jako przyjęcie na OIOM, wentylację mechaniczną lub zgon. Jednak po stratyfikacji astmy alergicznej (astma ze współistniejącym alergicznym zapaleniem błony śluzowej nosa bądź atopowego zapalenia skóry) $i$ astmy niealergicznej astma alergiczna nie wykazywała zwiększonego ryzyka ciężkich następstw (OR $=1,40$; CI 0,83-2,41). Astma niealergiczna wykazała znacznie zwiększone ryzyko ciężkiej choroby (OR = 4,09; CI 1,69-10,52) [25]. Podsumowując, te retrospektywne przeglądy sugerują, że astma nie jest związana ze zwiększonymi wskaźnikami przyjęć z powodu COVID-19 i że nie jest ona czynnikiem ryzyka ciężkiej choroby. Jednak nie ma danych wskazujących na to, że astma chroni przed ciężkim przebiegiem choroby COVID-19 [2].
Tabela 1. Badania potwierdzające brak zwiększenia ryzyka COVID-19 u pacjentów z astma.

\begin{tabular}{|l|c|c|c|}
\multicolumn{1}{|c|}{ Piśmiennictwo } & Kraj & $\begin{array}{c}\text { Współwystę- } \\
\text { powanie astmy } \\
\text { u pacjentów } \\
\text { z CoVID-19 }\end{array}$ & $\begin{array}{c}\text { Występowa- } \\
\text { nie astmy } \\
\text { w populacji } \\
\text { danego kraju }\end{array}$ \\
\hline $\begin{array}{l}\text { Zhang i wsp. [15] } \\
\text { Li i wsp. [16] }\end{array}$ & Chiny & $0,3-0,9 \%$ & $1,4 \%$ \\
\hline Ciprandi i wsp. [17] & Włochy & $2 \%$ & $6,63 \%$ \\
\hline Borobia i wsp. [18] & Hiszpania & $5,2 \%$ & $5-14,5 \%$ \\
\hline $\begin{array}{l}\text { Richardson i wsp. [19] } \\
\text { Lovinsky-Desir } \\
\text { i wsp. [20] }\end{array}$ & $\begin{array}{l}\text { USA (No- } \\
\text { wy Jork) }\end{array}$ & $9-12,6 \%$ & $13,6 \%$ \\
\hline Bhatraju i wsp. [21] & $\begin{array}{l}\text { USA } \\
\text { (Seattle) }\end{array}$ & $14 \%$ & $13,6 \%$ \\
\hline
\end{tabular}

\section{Znaczenie POChP w przebiegu COVID-19}

Niedawne badania wykazały zwiększoną ekspresję ACE2 (receptor dla SARS-CoV-2) w nabłonku oskrzeli i tkance płuc u pacjentów z POChP w porównaniu $\mathrm{z}$ grupą kontrolną oraz stwierdzono powiązanie wyższego poziomu ekspresji ACE2 z niższą czynnością płuc [26]. To może być jeden z mechanizmów powodujących, że chorzy na POChP są bardziej podatni na zakażenie koronawirusem i cięższy przebieg infekcji [27]. Dodatkowo, ze względu na charakter POChP, osoby cierpiące na tę chorobę są bardziej podatne na infekcje dróg oddechowych, w tym SARS-CoV-2. Podobnie jak w przypadku astmy koronawirusy bywają okresową przyczyną ostrych zaostrzeń POChP. Obserwuje się, że wśród pacjentów hospitalizowanych występowanie POChP jest istotnie skorelowane z większym nasileniem objawów COVID-19, co prowadzi do gorszego rokowania (tab. 2). Śmiertelność wzrosła również istotnie w przypadku współwystępowania COVID-19 i POChP. U co czwartego chorego, który zmarł w przebiegu COVID-19, rozpoznano POChP, a tylko 2,8\% pacjentów, u których zdiagnozowano obie choroby, przeżyło [28, 29]. Częstość występowania POChP wśród chorych na COVID-19 została przedstawiona w wielu metaanalizach (tab. 3) [27]. Pewnym wytłumaczeniem niższej częstości POChP wśród pacjentów z COVID-19 może być hipoteza mówiąca, że prawidłowe leczenie i kontrolowanie choroby zmniejsza ryzyko infekcji, w tym SARS-CoV-2 [30]. Kolejnym wytłumaczeniem może być objęcie szczególną, wczesną opieką i profilaktyką osób starszych i z wieloma chorobami współistniejącymi, w tym POChP [31]. Trzy kluczowe powiązania POChP i COVID-19 przedstawia tabela 4 [26]. 


\section{Wyzwania terapeutyczne}

Współwystępowanie COVID-19 z innymi przewlekłymi chorobami dróg oddechowych, takimi jak astma i POChP, stanowi nie lada wyzwanie terapeutyczne. Jak już wspomniano, choroby te mogą powodować cięższy przebieg infekcji, gorsze rokowanie, a zakażenie SARS-CoV-2 - zaostrzać chorobę podstawową. Ponadto początkowo sądzono, iż stosowanie inhalacji przyczynia się do znacznej transmisji wirusa [42, 43]. Kolejne badania pokazały jednak, iż zagrożenie zwiększonego przenoszenia się koronawirusa poprzez nebulizację, przy zachowaniu wszelkich środków bezpieczeństwa, jest niewielkie [44, 45]. Podobnie początkowo przedstawiano obawy co do stosowania glikokortykosteroidów (GKS) i ich wpływ na gorszy przebieg i rokowanie pacjentów z COVID-19. Wstępne obserwacje sugerowały, że chorzy, którzy zmarli z powodu COVID-19, częściej przyjmowali duże dawki GKS. Jednak na podstawie nowych danych wiemy, że GKS mogą korzystnie wpływać na przebieg infekcji poprzez zmniejszanie replikacji SARS-CoV-2 oraz ekspresji ACE2 (zmniejszenie produkcji interferonu typu 1) (tab. 4) [45, 46]. Tak więc, przy obecnym stanie wiedzy, chorym stosującym GKS należy zalecać kontynuowanie terapii. Potwierdzają to aktualne zalecenia Polskiego Towarzystwa Alergologicznego (PTA), które mówią, że w astmie oskrzelowej wziewne glikokortykosteroidy (wGKS) stanowią podstawę prze-

Tabela 2. Wplyw POChP u pacjentów z COVID-19 na rokowanie.

\begin{tabular}{|c|c|}
\hline Piśmiennictwo & $\begin{array}{c}\text { Riyzyko u pacjentów z POChP } \\
\text { RR }(95 \% \text { CI) }\end{array}$ \\
\hline \multicolumn{2}{|c|}{ Ryzyko hospitalizacji } \\
\hline $\begin{array}{l}\text { Argenziano [33] } \\
\text { Marcello [35] }\end{array}$ & $\begin{array}{l}1,0(0,9-1,1) \\
1,8(1,7-1,9)\end{array}$ \\
\hline \multicolumn{2}{|c|}{ Ryzyko przyjęcia na OІOM } \\
\hline $\begin{array}{l}\text { Alqahtani [32] } \\
\text { Argenziano [33] } \\
\text { Bartoletti [36] } \\
\text { Guan [34] }\end{array}$ & $\begin{array}{l}1,9(1,4-2,4) \\
0,9(0,6-1,4) \\
2,5(1,7-3,8) \\
6,8(3,4-13,9)\end{array}$ \\
\hline \multicolumn{2}{|c|}{ Ryzyko zgonu (wśród wszystkich zdiagnozowanych) } \\
\hline Marcello [35] & $1,9(1,5-2,3)$ \\
\hline \multicolumn{2}{|c|}{$\begin{array}{c}\text { Ryzyko zgonu } \\
\text { (wśród pacjentów hospitalizowanych) }\end{array}$} \\
\hline $\begin{array}{l}\text { Alqahtani [32] } \\
\text { Docherty [37] } \\
\text { Marcello [35] } \\
\text { Paranjpe [38] }\end{array}$ & $\begin{array}{l}1,1(0,6-1,8) \\
1,2(1,1-1,3) \\
1,1(0,9-1,3) \\
1,8(1,3-2,5)\end{array}$ \\
\hline \multicolumn{2}{|c|}{$\begin{array}{c}\text { Ryzyko zgonu } \\
\text { (wśród pacjentów w stanie krytycznym) }\end{array}$} \\
\hline Cummings [40] & $2,9(1,5-5,8)$ \\
\hline
\end{tabular}

wlekłego leczenia i w okresie epidemii SARS-CoV-2 powinny być stosowane zarówno u niezakażonych, jak i zakażonych pacjentów $\mathrm{z}$ astmą według przyjętych standardów. Przerwanie długotrwałego stosowania GKS może jedynie pogorszyć stan chorego. Tym bardziej że przy niepełnej kontroli astmy ataki kaszlu sprzyjają rozprzestrzenianiu się wirusa wśród bezobjawowych pacjentów [47]. Zarówno w astmie, jak i w POChP nie należy zmieniać metod leczenia ani przerywać terapii wziewnej [44]. PTA rekomenduje stosowanie wGKS $\mathrm{w}$ postaci ciśnieniowych inhalatorów (typu MDI, metered-dose inhaler) lub inhalatorów proszkowych (DPI, dry powder inhaler).

Tak więc w okresie pandemii koronawirusowej leczenie astmy i POChP musi być oparte na wypracowanych standardach. W astmie postępujemy zgodnie z wytycznymi Global Initiative for Asthma (GINA) [48], a w POChP z rekomendacjami Global Initiative for Chronic Obstructive Lung Disease (GOLD) [49]. Zaleca się, aby nie zmieniać planów terapii ustalonych przez lekarzy i aby pacjenci kontynuowali terapię wziewną. W przypadku ostrych zaostrzeń astmy lub POChP należy zawsze przeprowadzić różnicowanie. Objawy, które są charakterystyczne dla COVID19 , a z reguły nie występują w zaostrzeniach astmy i POChP, to: gorączka, brak apetytu, bóle mięśni, problemy żołądkowo-jelitowe [50]. Podsumowując obecne wytyczne, trzeba bardzo mocno podkreślić, że

Tabela 3. Występowanie POChP u pacjentów z COVID-19 na podstawie metaanaliz.

\begin{tabular}{|c|c|}
\hline Piśmiennictwo & $\begin{array}{c}\text { Częstość P0ChP } \\
\%(95 \% \text { CI) }\end{array}$ \\
\hline \multicolumn{2}{|c|}{ Wszyscy z dodatnim testem na SARS-CoV-2 } \\
\hline $\begin{array}{l}\text { Alqahtani [32] } \\
\text { Argenziano [33] } \\
\text { Guan [34] } \\
\text { Marcello [35] }\end{array}$ & $\begin{array}{l}2,0(1,0-3,0) \\
6,6(5,2-8,3) \\
1,0(0,6-1,9) \\
2,1(1,9-2,4)\end{array}$ \\
\hline \multicolumn{2}{|c|}{ Pacjenci hospitalizowani } \\
\hline $\begin{array}{l}\text { Argenziano [33] } \\
\text { Bartoletti [36] } \\
\text { Docherty [37] } \\
\text { Marcello [35] } \\
\text { Paranjpe [38] } \\
\text { Richardson [39] }\end{array}$ & $\begin{array}{l}6,6(5,1-8,5) \\
10,5(8,7-12,6) \\
17,7(17,2-18,3) \\
3,7(3,3-4,2) \\
5,1(4,3-6,1) \\
5,0(4,5-5,6)\end{array}$ \\
\hline \multicolumn{2}{|c|}{ Pacjenci w stanie krytycznym } \\
\hline $\begin{array}{l}\text { Argenziano [33] } \\
\text { Cummings [40] } \\
\text { Guan [34] }\end{array}$ & $\begin{array}{l}5,9(3,6-9,7) \\
9,3(6,3-13,6) \\
10,5(5,1-20,3)\end{array}$ \\
\hline \multicolumn{2}{|c|}{ Pacjenci zmarli } \\
\hline $\begin{array}{l}\text { Palmieri [41] } \\
\text { Marcello [35] } \\
\text { Paranjpe [38] }\end{array}$ & $\begin{array}{l}16,4(15,1-17,8) \\
4,0(3,2-5,0) \\
9,0(6,3-12,8)\end{array}$ \\
\hline
\end{tabular}


Tabela 4. Kluczowe związi POChP i COVID-19 (na podstawie [26]).

\begin{tabular}{|c|c|c|}
\hline $\begin{array}{c}\text { Mechanizmy, które mogą zwiększać } \\
\text { podatność na zakażenie SARS-CoV-2 } \\
\text { w POChP }\end{array}$ & $\begin{array}{l}\text { GKS i COVID-19 w POChP } \\
\text { (+) efekt korzystny } \\
\text { (-) efekt negatywny }\end{array}$ & $\begin{array}{l}\text { Rokowanie w COVID-19 u pacjentów } \\
\text { z POChP }\end{array}$ \\
\hline $\begin{array}{l}\text { - zwiększona ekspresja ACE2 w płucach } \\
\text { - zmniejszona ochrona przeciwwirusowa } \\
\text { - dysfunkcjonalne komórki śródbłonka } \\
\text { i zwiększona koagulopatia mogą pogor- } \\
\text { szyć przebieg kliniczny COVID-19 }\end{array}$ & $\begin{array}{l}\text { - GKS zapobiegają zaostrzeniom w eozynofilowej } \\
\text { POChP (+) } \\
\text { - GKS zmniejszają replikację SARS-CoV-2 (+) } \\
\text { - GKS zmniejszają ekspresję ACE2 poprzez zmniej- } \\
\text { - Gzenie produkcji interferonu typu } 1 \text { (+) } \\
\text { - GKS moga zmniejszać obronę przeciwwirusowa (-) }\end{array}$ & $\begin{array}{l}\text { - } \text { brak dowodów na zwiększoną częstość } \\
\text { zakażeń SARS-CoV-2 u pacjentów z POChP } \\
\text { - } \text { pacjenci z POChP są narażeni na } \\
\text { zwiększone ryzyko gorszych wyników } \\
\text { leczenia COVID-19, w tym zgonu }\end{array}$ \\
\hline
\end{tabular}

GKS - glikokortykosteroidy

schematy i metody leczenia astmy i POChP w dobie pandemii nie uległy zmianie.

Należy pamiętać, że zarówno w terapii astmy, jak i POChP obowiązuje zasada stosowania najmniejszych skutecznych dawek leków. Zwłaszcza w okresie pandemii COVID-19 stałe przestrzeganie zaleceń, kontrolowanie choroby i brak zaostrzeń są szczególnie ważne [51]. Aby zrealizować te zadania, należy bardzo dokładnie wytłumaczyć pacjentom istotę choroby, objawy sugerujące zaostrzenia i konieczność zgłoszenia się do lekarza oraz uświadomić im, jak istotne jest przestrzeganie zaleceń i codzienne przyjmowanie leków w odpowiedniej dawce. Bardzo dobrym ułatwieniem dla chorych jest stworzenie indywidulanego planu leczenia, z instrukcją przyjmowania leków wziewnych oraz listą objawów, które wymagają kontroli lekarskiej. Prawidłowa opieka na pacjentem wymaga nie tylko stosowania aktualnych schematów leczenia, ale również przekonania chorych o skuteczności takiego postępowania oraz kontroli realizacji zaleceń.

Obecnie w codziennej praktyce coraz częściej przeprowadzamy porady w formie telewizyty. Telewizyta nie może być jednak zastosowana jako wizyta pierwszorazowa, w celu rozpoznania astmy lub POChP. Jest ona dobrym rozwiązaniem w kontrolowaniu przebiegu choroby, a także w przypadku potrzeby podtrzymania terapii lub ewentualnej niewielkiej modyfikacji postępowania. Problem stanowi również to, że w trakcie telewizyty nie jesteśmy w stanie skontrolować techniki przyjmowania leków wziewnych w inhalacjach przez pacjenta. To bardzo ważny element skutecznego leczenia chorób układu oddechowego. Często niepowodzenie terapii inhalacyjnej jest spowodowane złą techniką lub zbyt małą dawką leku [52]. Odpowiedzią na ten problem może być inhalator Forspiro ${ }^{\circledR}$, który charakteryzuje się unikalnym mechanizmem poprawnej techniki inhalacji. Wydaje się, że w świetle aktualnej wiedzy inhalator ten zbliża się do idealnego przyszłościowego DPI. Jego najważniejszymi cechami są: prosta, kompaktowa budowa umożliwiająca intuicyjne używanie, minimalna liczba wymaganych czyn- ności przy stosowaniu, informacja zwrotna dla chorego o prawidłowym procesie inhalacji, niski koszt urządzenia i terapii inhalacyjnej, prosta technologia formulacji leku [53]. Chory korzystający z Forspiro ${ }^{\circledR}$ ma wiedzę, czy poprawnie się inhaluje, a tym samym skutecznie leczy. Dzieje się tak dzięki zespołowi ściśle powiązanych ze sobą elementów, takich jak m.in.: okienko kontrolne (wizualna kontrola wykorzystanych pasków blistra), numeracja każdej pojedynczej dawki, słyszalny system kliknięć - przy ładowaniu dawki oraz zamykaniu ustnika. Należy również podkreślić, że terapia łączona budezonidu $\mathrm{z}$ formoterolem, która jest rekomendowana już w astmie epizodycznej (pierwszy stopień), skutkuje przyjmowaniem znacznie niższej dawki sumarycznej GKS, a jednocześnie zmniejsza potrzebę stosowania leków ratunkowych [54]. Dodatkowym elementem, który w obecnych trudnych i ponurych czasach może rozświetlić naszą rzeczywistość i uprzyjemnić przyjmowanie leku, jest to, że inhalator Forspiro $^{\circledR}$ otrzymał nagrodę Red Dot za unikalny, przyjazny pacjentowi design. To Oscar designu. Doceniony został również mechanizm, który daje choremu możliwość samokontroli w zakresie tego, czy inhalacja przebiegła poprawnie. Inhalator został także nagrodzony za konstrukcję aluminiowego blistra, który doskonale zabezpiecza proszek przed zawilgoceniem [55].

\section{Podsumowanie}

Obecne dane na temat znaczenia astmy i POChP w częstości i przebiegu zakażenia SARS-CoV-2 są niejednoznaczne i wymagają dalszej obserwacji i oceny. Wiadomo, że u pacjentów z przewlekłymi chorobami płuc należy zachować szczególną ostrożność oraz zastosować odpowiednią terapię. Według GINA i GOLD zarówno chorzy na astmę, jak i POChP powinni kontynuować dotychczasowe leczenie podczas COVID-19. Wszystkie niezbędne zmiany w przyjmowaniu leku powinno się skonsultować ze specjalistą. Szczególną staranność należy zachować, udzielając porady za pomocą telewizyty. W takich sytuacjach zastosowa- 
nie nowoczesnych inhalatorów, mających możliwość informowania pacjenta o poprawności wykonania inhalacji, może się przyczynić do kompletnej kontroli astmy i POChP.

\section{Piśmiennictwo}

1. Huang C, Wang Y, Li X et al. Clinical features of patients infected with 2019 novel coronavirus in Wuhan, China. Lancet. 2020; 395: 497-506.

2. Timberlake DT, Strothman K, Grayson MH. Asthma, severe acute respiratory syndrome coronavirus-2 and coronavirus disease 2019. Curr Opin Allergy Clin Immunol. 2021; 21(2): 182-7.

3. Singhal T. A Review of Coronavirus Disease-2019 (COVID-19). Indian J Pediatr. 2020; 87(4): 281-6.

4. Han X, Li X, Xiao $Y$ et al. Distinct Characteristics of COVID-19 Infection in Children. Front Pediatr. 2021; 9: 619738.

5. Shi Y, Wang Y, Shao C et al. COVID-19 infection: the perspectives on immune responses. Cell Death Differ. 2020; 27: 14514

6. Xu Z, Shi L, Wang Y et al. Pathological findings of COVID-19 associated with acute respiratory distress syndrome. Lancet Respir Med. 2020; 8: 420-2.

7. Li X, Geng M, Peng Y et al. Molecular immune pathogenesis and diagnosis of COVID-19. J Pharm Anal. 2020; 10: 102-8.

8. Liu F, Li L, XuM et al. Prognostic value of interleukin-6, C-reactive protein, and procalcitonin in patient with COVID-19. J Clin Virol. 2020; 127: 104370.

9. Glowacka I, Bertram S, Herzog P et al. Differential downregulation of ACE2 by the spike proteins of severe acute respiratory syndrome coronavirus and human coronavirus NL63. $J$ Virol. 2010; 84: 1198-205.

10. Bunyavanich S, Do A, Vicencio A. Nasal gene expression of angiotensin-converting enzyme 2 in children and adults. JAMA. 2020; 323: 2427-9.

11. Leung $J$, Yang $C$, Tam A et al. ACE-2 expression in the small airway epithelia of smokers and COPD patients: implications for COVID-19. Eur Respir J. 2020; 55(5): 2000688.

12. Zhao $Q$, Meng M, Kumar $R$ et al. The impact of COPD and smoking history on the severity of COVID-19: a systemic review and meta-analysis. J Med Virol. 2020; 92: 1915-21.

13. Zheng Z, Peng F, Xu B et al. Risk factors of critical \& mortal COVID-19 cases: a systematic literature review and meta-analysis. J Infect. 2020; 146: 110-8.

14. Zheng $X, X u Y$, Guan $W$ et al. Regional, age and respiratory-secretion specific prevalence of respiratory viruses associated with asthma exacerbation: a literature review. Arch Virol. 2018; 163: 845-53.

15. Zhang J, Cao Y, Dong X et al. Distinct characteristics of COVID-19 patients with initial rRT-PCR-positive and rRT-
PCR negative results for SARS-CoV-2. Allergy. 2020; 75 : 1809-12.

16. Li X, Xu S, Yu M et al. Risk factors for severity and mortality in adult COVID-19 inpatients in Wuhan. J Allergy Clin Immunol. 2020; 146: 110-8.

17. Ciprandi G, Licari A, Filippelli $G$ et al. Children and adolescents with allergy and/or asthma seem to be protected from coronavirus disease. Ann Allergy Asthma Immunol. 2020; 125 : $361-2$.

18. Borobia A, Carcas A, Arnalich F et al. A cohort of patients with COVID-19 in a Major Teaching Hospital in Europe. $J$ Clin Med. 2020; 9: 1733.

19. Richardson S, Hirsch J, Narasimhan $M$ et al. Presenting characteristics, comorbidities, and outcomes among 5700 patients hospitalized with COVID-19 in the New York City Area. JAMA. 2020; 323: 2052-9.

20. Lovinsky-Desir S, Deshpande D, De A et al. Asthma among hospitalized patients with COVID-19 and related outcomes. $J$ Allergy Clin Immunol. 2020; 146: 1027-34.e4.

21. Bhatraju P, Ghassemieh B, Nichols $M$ et al. Covid-19 in critically ill patients in the Seattle Region - case series. $N$ Engl J Med. 2020; 382: 2012-22.

22. Lieberman-Cribbin W, Rapp J, Alpert $N$ et al. The impact of asthma on mortality in patients with COVID-19. Chest. 2020; 158: 2290-1.

23. Wang $Y$, Chen J, Chen $W$ et al. Does asthma increase the mortality of patients with COVID-19? A systematic review and meta-analysis. Int Arch Allergy Immunol. 2020; 22: 1-7.

24. Ssentongo P, Ssentongo AE, Heilbrunn ES et al. Association of cardiovascular disease and 10 other pre-existing comorbidities with COVID-19 mortality: a systematic review and meta-analysis. PLoS One. 2020; 15: e0238215.

25. Yang J, Koh H, Moon S et al. Allergic disorders and susceptibility to and severity of COVID-19: a nationwide cohort study. J All Clin Imm. 2020; 146: 790-8.

26. Higham A, Mathioudakis A, Vestbo J et al. COVID-19 and COPD: a narrative review of the basic science and clinical outcomes. Eur Respir Rev. 2020; 29(158): 200199.

27. Smith JC, Sausville EL, Girish V et al. Cigarette smoke exposure and inflammatory signaling increase the expression of the SARS-CoV-2 receptor ACE2 in the respiratory tract. Dev Cell. 2020; 53: 514-29.

28. Leung JM, Niikura M, Yang CWT et al. COVID-19 and COPD. Eur Respir J. 2020; 56: 2002108.

29. Simons SO, Hurst JR, Miravitlles $M$ et al. Caring for patients with COPD and COVID-19: a viewpoint to spark discussion. Thorax. 2020; 75: 1035-9.

30. Halpin DMG, Faner R, Sibila O et al. Do chronic respiratory diseases or their treatment affect the risk of SARS-CoV-2 infection? Lancet Respir Med. 2020; 8: 436-8.

31. Chu DK, Akl EA, Duda $S$ et al. Physical distancing, face masks, and eye protection to prevent person-to-person trans- 
mission of SARS-CoV-2 and COVID-19: a systematic review and meta-analysis. Lancet. 2020; 395: 1973-87.

32. Alqahtani JS, Oyelade T, Aldhahir AM et al. Prevalence, severity and mortality associated with COPD and smoking in patients with COVID-19: a rapid systematic review and meta-analysis. PLoS One. 2020; 15: e0233147.

33. Argenziano $M G$, Bruce SL, Slater CL et al. Characterization and clinical course of 1000 patients with coronavirus disease 2019 in New York: retrospective case series. BMJ. 2020; 369: m1996.

34. Guan WJ, Ni ZY, Hu Y et al. Clinical characteristics of coronavirus disease 2019 in China. NEngl J Med. 2020; 382: 1708-20.

35. Marcello RK, Dolle J, Grami S et al. Characteristics and outcomes of COVID-19 patients in New York City's Public Hospital System. PLoS One. 2020; 15(12): e0243027.

36. Bartoletti MGM, Scudeller L, Tedeschi S et al. Development and validation of a prediction model for severe respiratory failure in hospitalized patients with SARS-CoV-2 infection: a multicentre cohort study (PREDI-CO study) Clin Microbiol Infect. 2020; 26(11): 1545-53. http://doi.org/10.1016/j. cmi.2020.08.003.

37. Docherty AB, Harrison EM, Green CA et al. Features of 20 133 UK patients in hospital with covid-19 using the ISARIC WHO Clinical Characterisation Protocol: prospective observational cohort study. BMJ. 2020; 369: m1985.

38. Paranjpe I, Russak A, De Freitas JK et al. Clinical characteristics of hospitalized Covid-19 patients in New York City. medRxiv 2020. http://doi.org/10.1101/2020.04.19.20062117.

39. Richardson S, Hirsch JS, Narasimhan $M$ et al. Presenting characteristics, comorbidities, and outcomes among 5700 patients hospitalized with COVID-19 in the New York City area. JAMA. 2020; 323: 2052-9.

40. Cummings MJ, Baldwin MR, Abrams $D$ et al. Epidemiology, clinical course, and outcomes of critically ill adults with COVID-19 in New York City: a prospective cohort study. Lancet. 2020; 395: 1763-70.

41. Palmieri L, Vanacore $N$, Donfrancesco $C$ et al. Clinical characteristics of hospitalized individuals dying with COVID-19 by age group in Italy. J Gerontol A Biol Sci Med Sci. 2020; 75: 179-800.

42. Pirożyński M. Terapia wziewna - ze szczególnym uwzględnieniem steroidów - w okresie pandemii COVID-19. Alergia. 2020; 1: 4-6.

43. Verma S, Dhanak M, Frankenfield J. Visualizing the effectiveness of face masks in obstructing respiratory jets. Phys Fluids. (1994). 2020; 32(6): 061708.

44. Pirożyński M. Asthma during infection with particular attention to the COVID-19 pandemic. Alergoprofil. 2020; 16(4): 41-8.

45. Halpin D, Singh D, Hadfield R. Inhaled corticosteroids and COVID-19: a systematic review and clinical perspective. Eur Respir J. 2020; 55: 2001009.
46. Chhiba K, Patel G, Huyen T et al. Prevalence and characterization of asthma in hospitalized and nonhospitalized patients with COVID-19. J Allergy Clin Immunol. 2020; 146: 307-14.

47. Kowalski ML, Bartuzi Z, Bręborowicz A et al. Position statement of expert panel of the Polish Allergology Society on the management of patients with bronchial asthma and allergic diseases during SARS-CoV-2 pandemics. Alergol Pol. 2020; 7: $57-63$

48. Global Initiative for Asthma (GINA0. Global Strategy for Asthma Management and Prevention. 2020. www.ginaasthma. org (access: 7.04.2021).

49. Global Initiative for Chronic Obstructive Lung Disease, 2020. www.goldcopd.org (access: 7.04.2021).

50. Attaway A, Hatipoğlu U. Management of patients with COPD during the COVID-19 pandemic. Cleve Clin J Med. 2020. http://doi.org/10.3949/ccjm.87a.ccc007.

51. Waszczykowska K, Wegierska M, Drygała $R$ et al. Asth$m a$, chronic obstructive pulmonary disease (COPD) and asthma-COPD overlap syndrome and the risk of severe COVID-19. Alergologia Polska - Polish Journal of Allergology. 2021; 8(1): 21-30.

52. Emeryk A, Pirożyński M. Najważniejsze problemy nebulizacji u dzieci. Alerg Astma Immunol. 2013; 18(3): 140-4.

53. Emeryk A, Pirożyński M. Forspiro ${ }^{\circledR}$ - nowy inhalator suchego proszku. Czy zblizamy się do ideahu? Pneumonol Alergol Pol. 2016; 84(suppl 6): 64-9.

54. Papi A, Blasi F, Canonica GW et al. Treatment strategies for asthma: reshaping the concept of asthma management. Allergy Asthma Clin Immunol. 2020; 16: 75.

55. Sybilski AJ. Astma niekontrolowana. Alergoprofil. 2021; 17(1): $17-20$

ORCID

A.J. Sybilski - ID - http://orcid.org/0000-0003-2389-277X

Konflikt interesów/Conflict of interests:

Nie występuje.

Finansowanie/Financial support:

Nie występuje.

Etyka/Ethics:

Treści przedstawione w artykule są zgodne z zasadami Deklaracji Helsińskiej, dyrektywami EU oraz ujednoliconymi wymaganiami dla czasopism biomedycznych

Copyright: (C) Medical Education sp. z 0.0. This is an Open Access article distributed under the terms of the Attribution-NonCommercial 4.0 International (CC BY-NC 4.0). License (https://creativecommons.org/licenses/by-nc/4.0/), allowing third parties to copy and redistribute the material in any medium or format and to remix, transform, and build upon the material, provided the original work is properly cited and states its license.

Adres do korespondencji:

dr hab. n. med. Adam J. Sybilski, prof. CMKP II Klinika Pediatrii, Centrum Medyczne Kształcenia Podyplomowego, Centralny Szpital Kliniczny Ministerstwa Spraw Wewnętrznych i Administracji w Warszawie 02-507 Warszawa, ul. Wołoska 137 e-mail: adam.sybilski@cskmswia.pl 